\title{
Further observations on the murine model of Mycoplasma hominis infection
}

\author{
Correspondence \\ David Taylor-Robinson \\ taylorrobinsondavid@googlemail. \\ com
}

Received 30 January 2010

Accepted 29 April 2010

\author{
David Taylor-Robinson and Patricia M. Furr
}

Division of Medicine, Imperial College London, St Mary's Campus, Paddington, London W2 1NY, UK

\section{INTRODUCTION}

The first report of the isolation of a mycoplasma from a human subject was in 1937 (Dienes \& Edsall, 1937). The organisms were recovered, apparently in pure culture, from an abscess of Bartholin's gland. In retrospect, these organisms, which produced large colonies on agar, probably belonged to the species Mycoplasma hominis because this is the large-colony-forming species most frequently recovered from the genital tract. Over the last 70 years, the fact that this mycoplasma has been found as part of the normal flora of the human genital tract has complicated significantly clarification of its role in disease (TaylorRobinson, 1996). Nevertheless, it seems to have some role, to a greater or lesser extent, in upper urinary tract infections, bacterial vaginosis, pelvic inflammatory disease, prematurity, post-partum and post-abortal fever and respiratory distress in the newborn (Totten et al., 2008). $M$. hominis has been implicated also in some extra-genital infections, such as central nervous system and surgical wound infections and suppurative arthritis seen in individuals with hypogammaglobulinaemia (Furr et al., 1994). In a proportion of these conditions, a specific antibody response has also been detected which might be protective in the genital tract. This has never been established but the results of a study in which adult volunteers were given $M$. hominis organisms via the respiratory tract showed that those who possessed indirect haemagglutinating antibody

Abbreviations: c.c.u., colour-changing unit; CMI, cell-mediated immunity. were protected from the development of sore throats and cervical (neck) adenopathy (Taylor-Robinson et al., 1965). This apart, there is no information on the role of antibody in $M$. hominis infection. The fact that $M$. hominis has been shown to infect the genital tract of oestradiol-treated female mice (Furr \& Taylor-Robinson, 1989) opens an opportunity of exploring the protective effect or otherwise of antibody in the mouse model and may allow inferences to be drawn regarding human infection and disease.

\section{METHODS}

Mice. Female mice, $8-10$ weeks of age, were used. They were strains $\mathrm{BALB} / \mathrm{c}$ or $\mathrm{CBA}$ bred at the former Clinical Research Centre, Harrow, Middlesex, UK.

Hormone treatment. Oestradiol benzoate (Paines and Byrne) was given on four occasions at weekly intervals as a $0.5 \mathrm{mg}$ dose subcutaneously $(0.1 \mathrm{ml})$. In an attempt to eliminate a genital infection by $M$. hominis, mice that had been given oestradiol originally were treated with progesterone (Depo-Provera; Upjohn) given subcutaneously $(2.5 \mathrm{mg}$ in $0.2 \mathrm{ml})$ also on four occasions at weekly intervals (Taylor-Robinson \& Furr, 1990).

Medium. Liquid medium used for culturing M. hominis organisms and for isolating them from the mice was as described previously (Manchee \& Taylor-Robinson, 1968; Taylor-Robinson \& Furr, 1981). Briefly, it comprised beef heart infusion broth enriched with $20 \%$ $(\mathrm{v} / \mathrm{v})$ horse serum and $10 \%(\mathrm{v} / \mathrm{v}) 25 \%(\mathrm{w} / \mathrm{v})$ yeast extract, supplemented with $0.1 \%$ L-arginine hydrochloride, 1000 IU penicillin $\mathrm{G} \mathrm{ml}^{-1}$ and $0.002 \%$ phenol red. 
Inoculum and mouse inoculation. M. hominis strain MY17288 (our designation) was received originally from the late Dr B. E. Andrews (PHLS Laboratory, Norwich, UK) having been isolated from the blood of a woman with puerperal fever. It was subcultured three times in liquid medium before intravaginal or intravenous inoculation of the mice. Mice inoculated intravaginally were given $50 \mu \mathrm{l}$ instilled with an Eppendorf pipette. This inoculation coincided with the second dose of oestradiol.

Vaginal cytology. A vaginal nasopharyngeal swab (Medical Wire and Equipment) was inserted into the mouse vagina, rotated, removed and then rolled along a $3 " \times 1 "$ glass slide. The smear was fixed for $30 \mathrm{~min}$ in methanol and then stained with Giemsa. The phase of the reproductive cycle was determined by assessing the presence or absence of leukocytes and nucleated and cornified squamous epithelial cells (Rugh, 1968; Furr \& Taylor-Robinson, 1991). Following a dose of oestradiol and before receiving M. hominis, the mice were proved to be in the oestrous phase of the cycle by vaginal cytology.

Isolation and quantification of $\boldsymbol{M}$. hominis. The remaining contents of the vaginal swab were expressed in $1.8 \mathrm{ml}$ liquid medium contained in a screw-capped glass vial of $2.5 \mathrm{ml}$ capacity. This was regarded as a $10^{-1}$ dilution and further 10 -fold dilutions were made serially to $10^{-8}$, after which the vials were incubated at $37^{\circ} \mathrm{C}$ and observed every day for up to 2 weeks. Presumptive growth of $M$. hominis was indicated by a change in colour of the medium from yellow to pink. The last dilution at which a colour change occurred was deemed to contain 1 colour-changing unit (c.c.u.) of M. hominis (Taylor-Robinson et al., 1966).

Antibiotic treatment. Some mice were treated with oxytetracycline (Occrycetin; Willows Francis Veterinary), $6.0 \mathrm{mg}$ in $0.1 \mathrm{ml}$, given subcutaneously daily for 4 days (Taylor-Robinson \& Furr, 2000).

Measurement of antibody. Antibody to M. hominis was sometimes sought in sera and vaginal washings. A washing was obtained by introducing $50 \mu \mathrm{l}$ Dulbecco's PBS into the vagina using an Eppendorf pipette, reintroducing the fluid and withdrawing it. Washings and sera were inactivated at $56{ }^{\circ} \mathrm{C}$ for $30 \mathrm{~min}$ before being tested by use of the metabolism-inhibition technique (Purcell et al., 1966) using strain MY17288 of M. hominis.

Statistical evaluation. Groups of mice were compared using Fisher's exact test where appropriate. A probability $(P)$ value of $<0.05$ was regarded as significant.

\section{RESULTS}

\section{Vaginal colonization of BALB/c and CBA mice by M. hominis}

Previous observations (Furr \& Taylor-Robinson, 1993) had indicated that $\mathrm{BALB} / \mathrm{c}$ mice were more susceptible to Mycoplasma pulmonis (of murine origin) than were CBA mice. Thus, the susceptibility of these two mouse strains to vaginal colonization by $M$. hominis after pre-treatment with oestradiol was compared. Of $20 \mathrm{BALB} / \mathrm{c}$ mice inoculated with $5 \times 10^{6}$ c.c.u. of $M$. hominis, 19 (95\%) were colonized vaginally after 1 week, 16 after 3 weeks (titre range: $10^{4}-10^{8}$ c.c.u.) and 10 after 8 weeks (titre range: $10^{3}-$ $10^{7}$ c.c.u.) with the organisms persisting in two mice for up to 100 days. Of 20 CBA mice given the same size inoculum,
$18(90 \%)$ were colonized and the organisms persisted at a titre and for a duration similar to that seen in the BALB/c mice. Apart from a transient initial recovery of organisms in small numbers, sustained colonization of these strains of mice did not occur if they were pre-treated with progesterone instead of oestradiol.

\section{Effect of ovariectomy on genital tract colonization by M. hominis}

To determine the effect of naturally occurring oestrogen on colonization, the ovaries of $20 \mathrm{BALB} / \mathrm{c}$ mice were excised, a further group of mice without surgery being used as a control. Ten mice from each group received the usual regime of oestradiol, the other 10 remaining untreated. All 40 mice were each inoculated intravaginally with $2.5 \times 10^{7}$ of M. hominis. As shown in Table 1 , the vaginal colonization of mice that were not ovariectomized was no more frequent or greater than in ovariectomized mice that were given oestradiol. In other words, it seems that naturally occurring hormone did not make a significant contribution to colonization.

\section{Effect of hysterectomy on genital tract colonization by M. hominis}

It had been observed at autopsy previously (Furr \& TaylorRobinson, 1989) that M. hominis existed not only in the vagina, but sometimes in the uterine horns and ovaries and very occasionally in the throat of mice several weeks after intravaginal inoculation. This raised the question of whether the primary site of colonization might be in the upper genital tract, recovery of organisms from vaginal swabs simply being a reflection of their transmission from above. In an attempt to resolve this question, $\mathrm{BALB} / \mathrm{c}$ mice in two groups of five were hysterectomized at 3 weeks of

Table 1. Effect of ovariectomy on vaginal colonization with $M$. hominis in oestradiol-treated and untreated BALB/c mice

\begin{tabular}{|lcc|}
\hline Treatment & $\begin{array}{c}\text { No. mice colonized, titre (c.c.u.) range } \\
\text { and GMT* per group of 10 mice on } \\
\text { indicated day after inoculation }\end{array}$ \\
\cline { 2 - 3 } & 7 & 21 \\
\hline None & 0 & 0 \\
Oestradiol alone & 10 & 10 \\
& $10^{5}-10^{8}$ & $10^{6}-10^{8}$ \\
Ovariectomy alone & $1.0 \times 10^{7}$ & $1.2 \times 10^{7}$ \\
Ovariectomy and & 0 & 0 \\
oestradiol & 10 & 10 \\
& $10^{5}-10^{8}$ & $10^{5}-10^{8}$ \\
& $5.0 \times 10^{6}$ & $3.9 \times 10^{6}$ \\
\hline
\end{tabular}

${ }^{\star} \mathrm{GMT}$, geometric mean titre (c.c.u.). 
age, allowed to recover and at 7 weeks one group began the usual regime of oestradiol. Two other groups of five mice that had not been hysterectomized were treated similarly, one group being given oestradiol and the other remaining untreated. At the time of the second dose of oestradiol, all 20 mice were challenged intravaginally with $2.5 \times 10^{7}$ c.c.u. of $M$. hominis. After 7 and 14 days, large numbers of organisms were recovered from the vagina of hysterectomized mice given oestradiol and from those given oestradiol only, but not from hysterectomized or normal control mice that had not received oestradiol. The results suggest that hysterectomy did not prevent vaginal colonization and that infection at a site in the upper tract was not paramount for this to occur.

\section{Eradication of $\boldsymbol{M}$. hominis from the vagina}

Previous experience had indicated that eradication could be achieved by treating the mice with oxytetracycline, or by administering progesterone, or by leaving the mice until the organisms had disappeared spontaneously. In the current experiment (Table 2 ), of ten $\mathrm{BALB} / \mathrm{c}$ mice and ten CBA mice that had been colonized vaginally and then treated with the antibiotic, nine of the BALB/c mice and seven of the CBA mice were mycoplasma-free 14 days later and thereafter. Likewise, of nine mice of each strain given progesterone, all were mycoplasma-free after 14 days and subsequently. In addition, of five $\mathrm{BALB} / \mathrm{c}$ mice and ten CBA mice colonized initially, four of the former and eight of the latter were shown by 56 days to have become mycoplasma-free without any intervention. Thus, this was slow compared to the rapid clearing of organisms following antibiotic or progesterone administration, of which progesterone treatment seemed marginally to be the most effective.

Table 2. Vaginal colonization of BALB/c or CBA mice with $M$. hominis after treatment of previous colonization

\begin{tabular}{|llcc|}
\hline $\begin{array}{l}\text { No. of mice } \\
\text { colonized } \\
\text { initially }\end{array}$ & \multicolumn{1}{c}{$\begin{array}{c}\text { Mice treated } \\
\text { with: }\end{array}$} & $\begin{array}{c}\text { No. of mice } \\
\text { subsequently } \\
\text { mycoplasma-free* }\end{array}$ & $\begin{array}{c}\text { No. of mice } \\
\text { (\%) colonized } \\
\text { after } \\
\text { rechallenge }\end{array}$ \\
\hline BALB/c & & & \\
10 & Oxytetracycline & 9 & $8(89)$ \\
9 & Progesterone & 9 & $4(44)$ \\
5 & Nothing & 4 & $3(75)$ \\
CBA & Total & 22 & $15(68)$ \\
10 & Oxytetracycline & 7 & $7(100)$ \\
9 & Progesterone & 9 & $8(89)$ \\
10 & Nothing & 8 & $6(75)$ \\
& Total & 24 & $21(87)$ \\
\hline
\end{tabular}

*After 14 days in mice given oxytetracycline or progesterone and after 56 days in untreated mice.

\section{Vaginal colonization of mice previously infected vaginally}

As shown in Table 2, groups of BALB/c and CBA mice infected with $M$. hominis were treated as described above and then those from which $M$. hominis could not be recovered were rechallenged vaginally at the time of a second dose of oestradiol in a further course of the hormone. Of $22 \mathrm{BALB} / \mathrm{c}$ mice that were $M$. hominis-free, 15 (68\%) were susceptible on rechallenge; of 24 mycoplasmafree CBA mice, $21(87 \%)$ were susceptible, a difference that was not significant $(P=0.2$, Fisher's exact test). All mice that had not received $M$. hominis previously were susceptible to vaginal colonization. Overall, therefore, resistance to vaginal colonization was poor in mice that had recovered from a previous successful challenge.

\section{Vaginal colonization after intravenous inoculation of M. hominis}

Viable $\boldsymbol{M}$. hominis organisms. Three groups, each of 10 $\mathrm{BALB} / \mathrm{c}$ mice, were used. The first group received two intravenous inocula, 14 days apart, each of $5 \times 10^{6}$ c.c.u. of viable M. hominis. After a further 21 days, the inoculated mice, together with a group of 10 uninoculated controls, received the first of four doses of oestradiol. The second dose, 1 week later, coincided with the intravaginal inoculation of $2.5 \times 10^{7}$ c.c.u. of $M$. hominis, after which the mice were swabbed at intervals to determine whether vaginal colonization had occurred and persisted. As shown in Table 3, only two of the mice became colonized, one of these transiently, in contrast to the control mice, six of which were still colonized after 42 days. Thus, intravenous inoculation of viable organisms afforded at least $80 \%$ protection against vaginal colonization.

After a further 2 weeks (day 56), the original inoculated $\mathrm{BALB} / \mathrm{c}$ mice, together with a new group of controls of similar age, were started on a course of oestradiol and inoculated intravaginally with $2.5 \times 10^{7}$ c.c.u. of $M$. hominis. On this occasion, two of the mice inoculated previously were again positive transiently in comparison with the controls, nine of which became positive vaginally. Thus, it was clear that protection against vaginal colonization by $M$. hominis could be afforded by intravenous immunization with viable organisms. In complete contrast, however, this was not seen with CBA mice. Thus, of 10 such mice given $5 \times 10^{6}$ c.c.u. of viable $M$. hominis intravenously, all were colonized vaginally 7 and 14 days after receiving $2.5 \times 10^{7}$ c.c.u. of M. hominis intravaginally, in exactly the same way as 10 controls that had not been inoculated intravenously. Thus, there was no evidence of vaginal protection.

To make certain that the difference noted between the $\mathrm{BALB} / \mathrm{c}$ and CBA mice was not spurious, two groups of ten mice comprising the two strains were inoculated intravenously with $5 \times 10^{7}$ c.c.u. of viable $M$. hominis. After a further 2 weeks, both groups were inoculated again with 
Table 3. Effect of intravenous inoculation of BALB/c mice with $M$. hominis on vaginal colonization with the same viable mycoplasmal organisms

\begin{tabular}{|c|c|c|c|c|c|c|c|}
\hline \multirow[t]{2}{*}{ Treatment } & \multicolumn{7}{|c|}{$\begin{array}{l}\text { No. mice colonized, titre (c.c.u.) range and GMT }{ }^{\star} \text { per group of } 10 \text { mice on indicated day } \\
\text { after inoculation }\end{array}$} \\
\hline & 7 & 14 & 28 & 42 & $56 \dagger$ & 63 & 77 \\
\hline \multicolumn{8}{|l|}{ Intravenous } \\
\hline \multirow[t]{3}{*}{ M. hominis } & 2 & 1 & 1 & 0 & & 2 & 1 \\
\hline & $10^{3}-10^{5}$ & $10^{6}$ & $10^{7}$ & & & $10^{6}-10^{8}$ & $10^{4}$ \\
\hline & $6.3 \times 10^{0}$ & $3.9 \times 10^{0}$ & $5.0 \times 10^{0}$ & & & $2.5 \times 10^{1}$ & $2.5 \times 10^{0}$ \\
\hline \multirow[t]{3}{*}{ None } & 7 & 7 & 6 & 6 & & & \\
\hline & $10^{2}-10^{8}$ & $10^{4}-10^{8}$ & $10^{5}-10^{7}$ & $10^{5}-10^{6}$ & & & \\
\hline & $1.2 \times 10^{4}$ & $2.0 \times 10^{4}$ & $7.9 \times 10^{3}$ & $2.0 \times 10^{3}$ & & & \\
\hline \multirow[t]{3}{*}{ None } & & & & & & 9 & 9 \\
\hline & & & & & & $10^{4}-10^{8}$ & $10^{6}-10^{8}$ \\
\hline & & & & & & $1.0 \times 10^{6}$ & $1.2 \times 10^{6}$ \\
\hline
\end{tabular}

${ }^{\star}$ GMT, geometric mean titre (c.c.u.).

$\dagger$ Mice rechallenged intravaginally.

the mycoplasma, this time the inoculum containing $5 \times 10^{5}$ c.c.u. After another 3 weeks, these mice and a comparable group of uninoculated controls commenced a course of oestradiol. The second injection of the hormone, a week later, coincided with an intravaginal inoculation of $2.5 \times 10^{6}$ c.c.u. of $M$. hominis. As shown in Table 4, apart from the transient existence of a small number of $M$. hominis organisms in one BALB/c mouse, all ten of these

Table 4. Response of BALB/c and CBA mice to intravaginal inoculation of $M$. hominis after intravenous inoculation of the same viable mycoplasma

\begin{tabular}{|c|c|c|c|}
\hline \multirow[t]{2}{*}{$\begin{array}{l}\text { Mouse } \\
\text { strain }\end{array}$} & \multirow[t]{2}{*}{$\begin{array}{l}\text { Intravenous } \\
\text { inoculation }\end{array}$} & \multicolumn{2}{|c|}{$\begin{array}{l}\text { No. mice colonized, titre } \\
\text { (c.c.u.) range and GMT } \\
\text { per group of } 10 \text { mice on } \\
\text { indicated day after } \\
\text { intravaginal inoculation }\end{array}$} \\
\hline & & 7 & 21 \\
\hline $\mathrm{BALB} / \mathrm{c}$ & + & $\begin{array}{c}1 \\
10^{4} \\
2.5 \times 10^{0}\end{array}$ & 0 \\
\hline & - & $\begin{array}{c}10 \\
10^{2}-10^{8} \\
3.1 \times 10^{6}\end{array}$ & $\begin{array}{c}9 \\
10^{2}-10^{8} \\
5.0 \times 10^{5}\end{array}$ \\
\hline CBA & + & $\begin{array}{c}6 \\
10^{5}-10^{8} \\
7.9 \times 10^{3} \\
9 \\
10^{2}-10^{7} \\
1.0 \times 10^{5}\end{array}$ & $\begin{array}{c}6 \\
10^{5}-10^{8} \\
7.9 \times 10^{3} \\
9 \\
10^{3}-10^{8} \\
1.9 \times 10^{4}\end{array}$ \\
\hline
\end{tabular}

${ }^{\star} \mathrm{GMT}$, geometric mean titre (c.c.u.). mice were fully protected whereas, in contrast, only three of nine CBA mice were protected, a difference that was statistically significant ( $P=0.01$, Fisher's exact test).

Killed $\boldsymbol{M}$. hominis organisms. The protective effect of $M$. hominis, killed by heating at $56{ }^{\circ} \mathrm{C}$, given to $\mathrm{BALB} / \mathrm{c}$ mice intravenously was assessed. Viable $M$. hominis was used for comparison. Of three groups, each of 10 mice, the first received $5 \times 10^{7}$ c.c.u. of killed organisms, followed by $5 \times 10^{8}$ c.c.u. 14 days later. The second group was given similar inocula of viable organisms. The third group received arginine-containing medium and served as an unvaccinated control. One month after the second inoculation, oestradiol was given and again 1 week later, at which time mice in the three groups were challenged intravaginally with $2.5 \times 10^{7}$ c.c.u. of $M$. hominis. The results presented in Table 5 show that killed M. hominis organisms were at least as effective, if not more so, than viable ones in protecting $\mathrm{BALB} / \mathrm{c}$ mice against intravaginal challenge with $M$. hominis.

In contrast, an identical experiment undertaken in CBA mice with viable or killed organisms (Table 5) showed that they did not induce any protection against intravaginal challenge, a difference that was statistically significant $(P$ $<0.005$, Fisher's exact test).

\section{Relation of serum antibody to protection against vaginal colonization}

In previous experiments in the current study in which $\mathrm{BALB} / \mathrm{c}$ mice were used, there were 18 animals that had been colonized with $M$. hominis after intravaginal inoculation, but were then free of mycoplasmas and had metabolism-inhibiting serum antibody titres of $1:<16$. Of these, $15(83 \%)$ became recolonized after intravaginal 
Table 5. Effect of intravenous inoculation of BALB/c or CBA mice with killed or viable $M$. hominis organisms against vaginal colonization

\begin{tabular}{|c|c|c|c|}
\hline \multirow[t]{2}{*}{$\begin{array}{l}\text { Mouse } \\
\text { strain }\end{array}$} & \multirow[t]{2}{*}{$\begin{array}{l}\text { Intravenous } \\
\text { inoculum }\end{array}$} & \multicolumn{2}{|c|}{$\begin{array}{l}\text { No. mice colonized, titre (c.c.u.) } \\
\text { range and } \mathrm{GMT}^{\star} \text { per group of } \\
10 \text { mice on indicated day after } \\
\text { intravaginal inoculation }\end{array}$} \\
\hline & & 7 & 14 \\
\hline \multirow[t]{7}{*}{$\mathrm{BALB} / \mathrm{c}$} & Killed & 0 & 0 \\
\hline & Viable & 1 & 1 \\
\hline & & $10^{4}$ & $10^{5}$ \\
\hline & & $2.5 \times 10^{0}$ & $3.1 \times 10^{0}$ \\
\hline & None & 8 & 7 \\
\hline & & $10^{2}-10^{8}$ & $10^{6}-10^{7}$ \\
\hline & & $3.1 \times 10^{5}$ & $3.9 \times 10^{4}$ \\
\hline \multirow[t]{9}{*}{ CBA } & Killed & 10 & 10 \\
\hline & & $10^{4}-10^{8}$ & $10^{5}-10^{8}$ \\
\hline & & $3.9 \times 10^{6}$ & $7.9 \times 10^{6}$ \\
\hline & Viable & 10 & 10 \\
\hline & & $10^{4}-10^{7}$ & $10^{5}-10^{8}$ \\
\hline & & $7.9 \times 10^{5}$ & $6.3 \times 10^{5}$ \\
\hline & None & 10 & 10 \\
\hline & & $10^{5}-10^{8}$ & $10^{6}-10^{8}$ \\
\hline & & $5.0 \times 10^{6}$ & $3.1 \times 10^{7}$ \\
\hline
\end{tabular}

${ }^{\star} \mathrm{GMT}$, geometric mean titre (c.c.u.).

challenge. There were 6 mice that had also been colonized with $M$. hominis after intravaginal inoculation; they became free of the organisms but had antibody titres of $1: 32$ or greater. Of these, only one (16\%) became recolonized after intravaginal challenge.

In the experiments in which mice were given viable $M$. hominis organisms intravenously, a range of metabolisminhibiting antibody titres from $1:<16$ to $1: 512$ (geometric mean of $1: 120)$ was seen. The mouse having an antibody titre of $1:<16$ was susceptible to vaginal colonization, whereas all those with higher antibody titres were resistant. Mice receiving killed organisms exhibited antibody titres ranging from $1: 32$ to $1: 128$ (geometric mean of $1: 56$ ). None of these mice was susceptible to vaginal colonization. All control mice unexposed previously to M. hominis had antibody titres of $1:<8$ and all were colonized when challenged intravaginally. Antibody was not detected in any of the vaginal washings.

\section{DISCUSSION}

It was shown previously (Furr \& Taylor-Robinson, 1989) that the prototype strain (PG 21) of M. hominis was incapable of colonizing the genital tract of mice probably because of the large number of passes it had received in vitro. Thus, in this study, the MY17288 strain of M. hominis was used and several unresolved issues have been addressed. Oestrogen occurring naturally in the mouse makes no contribution to the ostensible vaginal colonization by $M$. hominis. Endogenous oestrogen might play a part if the dose of oestradiol administered was much smaller. Apart from the influence of the oestradiol dose on the duration of recovery of organisms from the vagina, the size of the M. hominis inoculum in terms of the number of c.c.u. was important. As shown previously (Furr \& Taylor-Robinson, 1989), recovery could be made to extend beyond 200 days in a few mice. However, a relatively large dose was used to ensure a continued effect. It is also clear from the observations on hysterectomized mice that the continued existence of organisms in the lower genital tract is unlikely to be due to 'reseeding' from those that have colonized the upper tract. As might be expected, transmission is from the lower to upper tract. For convenience we refer to colonization of the lower genital tract as vaginal colonization when, in fact, vaginal swabbing does not allow a distinction to be made between colonization of the vagina and colonization of the uterine cervix. The truth, based on scanning and immunoelectron microscopical observations (Furr et al., 1995), is that the cervix is the primary focus of colonization. This may also be the case in the human situation where M. hominis organisms 'picked up' on a vaginal swab could, in fact, originate from infection in the cervix.

Regarding the immunological aspects, attempts were made to understand the manner in which protection against vaginal colonization was induced. In the case of $M$. pulmonis, studied previously (Furr \& Taylor-Robinson, 1984), protection occurred following colonization of the genital tract. However, neither viable nor killed $M$. pulmonis organisms given intravenously prevented colonization on intravaginal challenge, despite the stimulation of high titres of specific serum antibody, although elimination of organisms from the genital tract of mice given viable organisms intravenously was faster than observed in mice given killed organisms (TaylorRobinson \& Furr, 1994). In the case of M. hominis, previous vaginal colonization and subsequent elimination of organisms resulted in the mice being protected poorly against rechallenge, although there was an inverse relation between the presence of serum antibody and protection; mice with antibody were protected, while those without were not. In addition, a result somewhat different from that seen with $M$. pulmonis was observed when viable or killed M. hominis organisms were given intravenously. Both viable and killed organisms provided protection and, again, there was an inverse relation with antibody stimulated in high titre. However, protection was seen only in $\mathrm{BALB} / \mathrm{c}$ mice and not at all when CBA mice were used. This points to involvement of a genetic factor in the outcome of challenge in vaccinated mice, despite the response of both mouse strains to primary intravaginal challenge being similar, and indicates that the mechanisms of protection against M. pulmonis and M. hominis are not the same. 
A role for cell-mediated immunity (CMI) in protection was implied by the previous failure to colonize the genital tract of mice with M. pulmonis subsequent to colonization of the respiratory tract by this mycoplasma (Taylor-Robinson \& Furr, 1994). More evidence for CMI was seen when thymus-deficient nude mice failed to respond in the same way as immunocompetent mice, the former becoming colonized vaginally (Furr \& Taylor-Robinson, 1993). The mechanism was, presumably, one of migration of sensitized lymphocytes from the submucosa of the respiratory tract to that of the genital tract (Roitt et al., 1985). A similar phenomenon was seen with the inability to colonize the genital tract of mice with Mycoplasma pneumoniae when they were already colonized in the respiratory tract (Furr \& Taylor-Robinson, 1999). CMI has also been noted to play some part in the elimination of $M$. pulmonis from the genital tract of mice by treatment with oxytetracycline; thus elimination was successful in immunocompetent mice but failed completely in athymic nude mice (Taylor-Robinson \& Furr, 2000). By analogy, it is likely that CMI also contributes to the elimination of $M$. hominis from the genital tract of immunocompetent $\mathrm{BALB} / \mathrm{c}$ mice, but attempts to prove that this was so by using nude mice failed because of the rapid death of these mice following intravaginal inoculation of M. hominis. Whether loss of vaginal M. hominis organisms from mice untreated with progesterone or antibiotic is due entirely to a possible diminishing effect of oestradiol with the passage of time ('natural' elimination) or is assisted by cellular immune mechanisms is a moot point.

\section{REFERENCES}

Dienes, L. \& Edsall, G. (1937). Observations on the L-organism of Klieneberger. Proc Soc Exp Biol Med 36, 740-744.

Furr, P. M. \& Taylor-Robinson, D. (1984). Enhancement of experimental Mycoplasma pulmonis infection of the mouse genital tract by progesterone. J Hyg (Lond) 92, 139-144.

Furr, P. M. \& Taylor-Robinson, D. (1989). Oestradiol-induced infection of the genital tract of female mice by Mycoplasma hominis. J Gen Microbiol 135, 2743-2749.

Furr, P. M. \& Taylor-Robinson, D. (1991). The influence of hormones on the bacterial flora of the murine vagina and implications for human disease. Microb Ecol Health Dis 4, 141-148.

Furr, P. M. \& Taylor-Robinson, D. (1993). The contrasting effects of progesterone and oestrogen on the susceptibility of mice to genital infection with Mycoplasma pulmonis. J Med Microbiol 38, 160-165.

Furr, P. M. \& Taylor-Robinson, D. (1999). Colonization of the respiratory and genital tracts of female mice with Mycoplasma pneumoniae and protection afforded to the genital tract by prior respiratory colonization. Int J Exp Pathol 80, 35-39.

Furr, P. M., Taylor-Robinson, D. \& Webster, A. D. B. (1994). Mycoplasmas and ureaplasmas in patients with hypogammaglobulinaemia and their role in arthritis: microbiological observations over twenty years. Ann Rheum Dis 53, 183-187.

Furr, P. M., Sarathchandra, P., Hetherington, C. M. \& TaylorRobinson, D. (1995). Site of localization of Mycoplasma pulmonis and Mycoplasma hominis in the genital tract of female mice demonstrated by culture and scanning and immuno-electron microscopy. Int J Exp Pathol 76, 131-143.

Manchee, R. J. \& Taylor-Robinson, D. (1968). Haemadsorption and haemagglutination by mycoplasmas. J Gen Microbiol 50, 465-478.

Purcell, R. H., Taylor-Robinson, D., Wong, D. C. \& Chanock, R. M. (1966). A color test for the measurement of antibody to the non-acidforming human Mycoplasma species. Am J Epidemiol 84, 51-66.

Roitt, I. M., Brostoff, J. \& Male, D. K. (editors) (1985). Immunology, pp. 3.7-3.8. Edinburgh: Churchill Livingstone.

Rugh, R. (1968). The Mouse. Its Reproduction and Development, pp. 38-39. Minneapolis: Burgess Publishing Co.

Taylor-Robinson, D. (1996). Infections due to Mycoplasma and Ureaplasma: an update. Clin Infect Dis 23, 671-682.

Taylor-Robinson, D. \& Furr, P. M. (1981). Recovery and identification of human genital tract mycoplasmas. Isr J Med Sci 17, 648-653.

Taylor-Robinson, D. \& Furr, P. M. (1990). Elimination of mycoplasmas from the murine genital tract by hormone treatment. Epidemiol Infect 105, 163-168.

Taylor-Robinson, D. \& Furr, P. M. (1994). Protection of mice against vaginal colonisation by Mycoplasma pulmonis. J Med Microbiol 40, 197-201.

Taylor-Robinson, D. \& Furr, P. M. (2000). Observations on the antibiotic treatment of experimentally induced mycoplasmal infections in mice. J Antimicrob Chemother 45, 903-907.

Taylor-Robinson, D., Ludwig, W. M., Purcell, R. H. \& Mufson, M. A. (1965). The significance of antibody to Mycoplasma hominis type 1 as measured by indirect hemagglutination. Proc Soc Exp Biol Med 118, 1073-1083.

Taylor-Robinson, D., Purcell, R. H., Wong, D. C. \& Chanock, R. M. (1966). A colour test for the measurement of antibody to certain mycoplasma species based upon the inhibition of acid production. J Hyg (Lond) 64, 91-104.

Totten, P. A., Taylor-Robinson, D. \& Jensen, J. S. (2008). Genital mycoplasmas. In Sexually Transmitted Diseases, 4th edn, pp. 709-736. Edited by K. K. Holmes and others. London: McGraw Hill. 